\title{
EFFECT OF PARTIAL REPLACEMENT OF NATURAL SAND WITH CRUSHED SAND ALONG WITH SUPPLEMENTARY CEMENTING MATERIALS (FLY ASH AND GGBS)
}

\author{
Karan Verma ${ }^{1}$, P.S.Pajgade ${ }^{2}$ \\ ${ }^{I}$ Post Graduate Student, Department of Civil Engineering, P.R.M.I.T\&R., Badnera(Amravati), India \\ ${ }^{2}$ Proffesor, Department of Civil Engineering, P.R.M.I.T\&R., Badnera(Amravati), India
}

\begin{abstract}
The effect of partial replacement of natural sand (NS) by crushed sand (CS) and partial replacement of cement by supplementary cementing material have been investigated. All the trials have been taken at actual construction site and tested at site laboratory. Supplementary Cementing materials (SCM) Fly Ash and GGBS have been used and cement has been replaced by three combination of Fly ash $(15 \%, 20 \%, 25 \%)$ and two combinations of GGBS (40\% \& 50\%). In both the cases, 50\% natural sand have been replaced by crushed sand .Both the materials have shown good compatible results when used and it is found that use of SCM gives better result in terms of compressive strength and workability due to reduction in w/c ratio. This paper puts forward the applications of crushed sand and supplementary cementing materials as an attempt towards sustainable development. It will help to find viable solution to the declining availability of natural sand to make eco-balance.
\end{abstract}

Keywords: Crushed Sand (CS), Natural Sand (NS), Fly Ash (FA), Ground Granulated Blast Furnace Slag (GGBS), Admixture.

\section{INTRODUCTION}

The purpose for taking up this investigation is due to fact that natural sand (NS) confirming to Indian Standards is becoming scarcer and costlier due to its non availability in time, because of government laws and acts of Land, illegal dredging done by sand mafia, non-accessibility to the river source during rainy season and non confirming with IS requirements. Along with this, global warming and environmental destruction have become manifest problems in recent years, heighten concern about global environmental issues, and a change over from the massproduction, mass-consumption, mass-waste society of the past to a zero-emission society is now viewed as important. Preventing the exhaustion of natural resources and enhancing the usage of waste materials has become a significant problem of the modern world. Every year million tons of waste materials come into existence and a lot of studies have been carried out concerning the protection of natural resources. The world needs an environmentally friendly construction material. Concrete is basically made of aggregates glued by a cement paste which is made of cement and water. The current concrete construction practice is unsustainable because, it consumes around one billon ton a year of cement, which is not an environment friendly material. The production of cement is characterized by huge consumption of energy and emission of large quantities of $\mathrm{CO} 2$ gas.

Hence the present investigation was taken up with a view to verify the suitability, feasibility and potential use of crushed sand as replacement to natural sand in concrete mixes along with partial replacement of cement by Fly Ash and Ground Granulated Blast Furnace Slag(GGBS), in context of its compressive strength and workability in terms of slump. The Incorporation of both SCM and crushed sand will ultimately reduce the environmental impact due to concrete production by civil industry.

\subsection{Research Significance}

One main objectives of this research was to produce data from a systematic investigation so as to contribute to the development in use of crushed sand as fine aggregate $\&$ to promote use of supplementary cementitious material like Fly Ash or GGBS with view of making not only a environmental friendly concrete but also to produce a more durable concrete which cannot be produced by just using Ordinary Portland Cement alone. For the purpose of experimentation M-25 was chosen. A water reducing plasticizer was used to maintain the slump. High workable slump (between $100 \mathrm{~mm}$ to $150 \mathrm{~mm}$ ) as required at actual site conditions were trials were taken (Teosa ,Dist. Amravati, Maharashtra ) was maintained for all the trials. On this aspect research on concrete with manufactured sand and supplementary is scarce, so this paper investigates the concrete produced with manufactured sand and supplementary cementing materials.

\section{MATERIALS}

The properties of material used for making concrete mix are determined in laboratory as per relevant codes of practice. Different materials used in present study were cement, 
coarse aggregates, fine aggregates, in addition to Supplementary Cementing Materials (SCM) and admixture. The aim of studying of various properties of material is used to check the appearance with codal requirements and to enable design of concrete mix for a particular strength. The description of various materials which were used in this study is given below:

\subsection{Cement}

Ordinary Portland Cement (OPC) of 43 Grade (BIRLA) from a single lot was used throughout the course of the investigation. It was fresh and without any lumps. The physical properties of the cement as determined from various tests conforming to Indian Standard are listed in Table 1 (as supplied by manufacturer). Cement was carefully stored to prevent deterioration in its properties due to contact with the moisture.

Table 1 Properties of OPC 43 Grade Cement

\begin{tabular}{|l|l|l|}
\hline Sr. No. & Names of Lab Test & Result \\
\hline 1 & Fineness. (Sqm/kg) & 296 \\
\hline 2 & Initial Setting Time & $170 \mathrm{~min}$ \\
\hline 3 & Final Setting Time & $265 \mathrm{~mm}$ \\
\hline 4 & 7 days Compressive Strength. & $45.5 \mathrm{~N} / \mathrm{mm}^{2}$ \\
\hline 5 & 28 days Compressive Strength & $65.5 \mathrm{~N} / \mathrm{mm}^{2}$ \\
\hline 6 & $\begin{array}{l}\text { Standard consistency on } \\
\text { cement paste }\end{array}$ & $28.5 \%$ \\
\hline 7 & Specific Gravity & 3.15 \\
\hline
\end{tabular}

\subsection{Aggregates}

Coarse aggregate $(\mathrm{CA} \mathrm{I}=12 \mathrm{~mm}$ and $\mathrm{CA} I \mathrm{II}=20 \mathrm{~mm})$ was used, which was manufactured from locally available rock. Fines aggregate used was natural and manufactured Sand as available from local sources. Summary of material properties were presented in tables below:

Table2: Physical Properties of Natural Sand. (Kanhan Sand)

\begin{tabular}{|l|l|l|}
\hline Sr.No. & Name of Lab Test & Result \\
\hline 1 & Source & Kanhan \\
\hline 2 & Specific gravity & 2.7 \\
\hline 3 & Fineness modulus & 2.7 \\
\hline 4 & DLBD (kg/L) & 1.88 \\
\hline
\end{tabular}

Table3: Properties of Crushed Sand.

\begin{tabular}{|l|l|l|}
\hline Sr.No. & Name of Lab Test & Result \\
\hline 1 & Source & $\begin{array}{l}\text { Sawardi } \\
\text { Quarry }\end{array}$ \\
\hline 2 & Specific gravity & 2.73 \\
\hline 3 & Water absorption & 3.83 \\
\hline 4 & Fineness modulus & 3.42 \\
\hline 5 & DLBD $(\mathrm{kg} / \mathrm{L})$ & 1.84 \\
\hline
\end{tabular}

Table 4: Properties of CA I.

\begin{tabular}{|l|l|l|}
\hline Sr.No. & Name of Lab Test & Result \\
\hline 1 & Source & Sawardi Quarry \\
\hline 2 & Shape & $\begin{array}{l}\text { Crushed Rock } \\
\text { aggre. }\end{array}$ \\
\hline 3 & Maximum size $(\mathrm{mm})$ & $12 \mathrm{~mm}$ \\
\hline 4 & Water absorption & 0.94 \\
\hline 5 & DLBD (kg/L) & 1.61 \\
\hline 6 & Specific gravity & 2.91 \\
\hline
\end{tabular}

Table 5: Properties of CA II.

\begin{tabular}{|l|l|l|}
\hline Sr.No. & Name of Lab Test & Result \\
\hline 1 & Source & $\begin{array}{l}\text { Sawardi } \\
\text { Quarry }\end{array}$ \\
\hline 2 & Shape size & $\begin{array}{l}\text { Crushed } \\
\text { Rock aggre. }\end{array}$ \\
\hline 3 & $\begin{array}{l}\text { Maximum } \\
\text { (mm) }\end{array}$ & 0.92 \\
\hline 4 & Water absorption & 1.59 \\
\hline 5 & DLBD (kg/L) & 2.93 \\
\hline 6 & Specific Gravity & \\
\hline
\end{tabular}

\subsection{Fly Ash}

Fly ash, known also as pulverized - fuel ash, is the ash precipitated electro-statically from the exhaust fumes of coal-fired power stations, and is the most common artificial pozzolana. During combustion of powdered coal in modern power plants, as coal passes through high temperature zone in the furnace, the volatile matter $\&$ carbon are burned off, whereas most of the mineral impurities, such as clays, quartz, and feldspar, will melt at high temperature. The fused matter will be quickly transported to lower temperature zones where it solidifies as spherical particles of glass. Some of the mineral matter agglomerates forming bottom ash, but most of it flies out with the flue gas stream and is called fly ash. This ash is subsequently removed from the gas by electrostatic precipitators. Locally available Fly ash confirming to codal requirement was made used for experimental purpose.

\subsection{Ground Granulated Blast Furnace Slag}

Ground-granulated blast-furnace slag (GGBS or GGBFS) is made by quenching molten iron Slag (a by-product of iron and steel-making) from a blast furnace in steam or water, to produce a glassy, granular product that is then dried and ground into a fine powder. Like Ordinary Portland Cement, GGBS is also a crushed material and therefore has angular shape but its surface texture is smoother as compare to OPC. This results in an improvement in workability. Also GGBS has a slightly lower relative density than that of the OPC (2.9 as compared to 3.1). Replacement on an equal mass-tomass basis will result in an increase in powder volume, which leads to an increase in workability. The use of GGBS is often accompanied by reduced w/c ratio for equivalent cohesion and flow. The reduction in water content for constant workability is influenced by the percentage of GGBS, the total cementitious material content and the 
particle size distribution of the powders. GGBS packed and processed by of SONA ANALYSIS company was made used in the experiments. From the manufacturers certificate of composition it is found that the material satisfies the codal requirement.

\subsection{Admixtures}

Admixtures are substances which are added to the concrete mix to give it more desirable properties. A plasticizer (water reducing agent) was used because of its ability to dramatically increase the workability of fresh concrete with minimal effect on the overall strength of the concrete. Water reducing plasticizer has a detergent like property which is referred to as a surface active agent. These substances carry an unbalanced charge of electricity and when put into water will migrate towards the surface of the water with the electrically charged end sticking into the water whilst the tale is out of the water. Masterplast PL-1, was used as plasticizer.

\section{EXPERIMENTAL PROGRAM}

The entire experimental program was carried out at actual site of a building project, hence there was no need to obtain the $28^{\text {th }}$ day compressive strength on higher side of $25 \mathrm{MPa}$ due to considerations for standard deviations caused due to site control conditions as compare to laboratory conditions. And also for a given w/c ratio better idea regarding the workability attain on actual site conditions was assed. Initially three different mixes consisting $100 \%$ crushed sand , $100 \%$ natural sand and 50\% crushed \& 50\% natural sand were prepared. Then with $50 \%$ crushed and $50 \%$ natural sand mix ,three more trial mix ,in which cement was replaced by fly ash in 3 proportion $15 \%, 20 \%$ and $25 \%$ respectively were casted and tested. Again with $50 \%$ crushed sand and natural sand mix two more trial mix in which cement was replaced by GGBS in two proportion of $40 \%$ and $50 \%$, were casted and tested. This replacement proportion of cement is decided empirically, as the objective of our study was to investigate the effect of use of SCM with crushed sand and was not to find any optimum replacement percentage of cement. The table no. 06 gives short notation for different mixes casted and tested. The different mixes followed are mentioned below in table 07.The slump recorded are mentioned below in table no.08.

Table 6: Mix nomenclature by no. for notation purpose

\begin{tabular}{|l|l|}
\hline Mix & No. \\
\hline $100 \%$ CS & 1 \\
\hline $100 \%$ NS & 2 \\
\hline $50 \%$ CS \& 50\%NS & 3 \\
\hline $50 \%$ CS \&50\% NS \& 15\% FA & 4 \\
\hline $50 \%$ CS \&50\% NS \& 20\% FA & 5 \\
\hline $50 \%$ CS \&50\% NS \& 25\% FA & 6 \\
\hline $50 \%$ CS \&50\% NS \& 40\% GBBS & 7 \\
\hline $50 \%$ CS \&50\% NS \& 50\% GBBS & 8 \\
\hline
\end{tabular}

Table 7: Mix Proportion for various trials. (kg/cubic meters)

\begin{tabular}{|c|c|c|c|c|c|c|c|c|c|}
\hline $\begin{array}{l}\mathbf{M} \\
\mathbf{i} \\
\mathbf{x}\end{array}$ & $\begin{array}{l}\mathbf{2 0} \\
\mathbf{m} \\
\mathbf{m}\end{array}$ & $\begin{array}{l}\mathbf{1 0} \\
\mathbf{m} \\
\mathbf{m}\end{array}$ & CS & $\mathbf{N S}$ & $\begin{array}{l}\text { Ce } \\
\text { me } \\
\text { nt }\end{array}$ & w/c & $\begin{array}{l}\text { Wa } \\
\text { ter } \\
\text { (L) }\end{array}$ & $\begin{array}{l}\text { Ad } \\
\text { mix } \\
\text { tue }\end{array}$ & $\begin{array}{l}\text { SC } \\
\mathbf{M}\end{array}$ \\
\hline 1 & 679 & 417 & 838 & 0 & 340 & 0.5 & 170 & 3.4 & 0 \\
\hline 2 & 722 & 443 & 0 & 881 & 340 & 0.35 & 119 & 3.4 & 0 \\
\hline 3 & 706 & 433 & 436 & 431 & 340 & 0.42 & 143 & 3.4 & 0 \\
\hline 4 & 714 & 438 & 440 & 436 & 290 & 0.38 & 129 & 2.72 & 50 \\
\hline 5 & 719 & 441 & 443 & 439 & 275 & 0.36 & 122 & 2.72 & 65 \\
\hline 6 & 725 & 445 & 447 & 442 & 255 & 0.36 & 122 & 2.72 & 85 \\
\hline 7 & 724 & 444 & 447 & 442 & 204 & 0.36 & 120 & 2.75 & 140 \\
\hline 8 & 719 & 441 & 443 & 439 & 172 & 0.35 & 124 & 2.75 & 172 \\
\hline
\end{tabular}

Table 8: Slump recorded at site for various trials.

\begin{tabular}{|l|l|l|}
\hline Mix & Initial Slump(mm) & $\begin{array}{l}\text { w/c } \\
\text { ratio }\end{array}$ \\
\hline $100 \%$ CS & 120 & 0.5 \\
\hline $100 \%$ NS & 130 & 0.35 \\
\hline $50 \%$ CS \& 50\% NS & 125 & 0.42 \\
\hline $50 \%$ CS \& 15\% FA & 125 & 0.38 \\
\hline $50 \%$ CS \& 20\% FA & 125 & 0.36 \\
\hline $50 \%$ CS \& 25\% FA & 120 & 0.36 \\
\hline $50 \%$ CS \& 40\% GGBS & 120 & 0.36 \\
\hline $50 \%$ CS \& 50\% GGBS & 125 & 0.35 \\
\hline
\end{tabular}

\section{RESULT AND CONCLUSIONS}

The results from various trials are plotted in form of graph as shown below in chart $1 \& 2$. And from the results obtained following conclusions can be drawn :

1) The $100 \%$ crushed sand mix, when used with the same dose of plasticizer, did not gave us the required strength.

2) The w/c ratio required for mix with $100 \%$ crushed sand to gain the required workability is found to be maximum .i.e. 0.5 as compare to any other mix in our experimental program. The possible reason behind this is the presence of irregular and very fine particle in crushed sand which needs more water to form the paste. The presence of this high w/c ratio in $100 \%$ crushed sand mix had lead to reduction in strength in this mix as compare to any other mix in our table.

3) As we move on graph from $100 \%$ crushed sand to $100 \%$ natural sand, we can find that there is increase in the compressive strength and reduction in the w/c ratio. ( It should be noted that this increase in strength and reduction in w/c ratio is for the same dose of admixture)

4) This indicate that natural sand is requiring less water to attain the desired workability and hence showing increase in strength due to reduction in w/c ratio. Thus if the manufacturing of crushed sand is done in such a way that its gradation matches the required standard gradation of fine aggregate, its water demand will reduce and will lead to better results. 


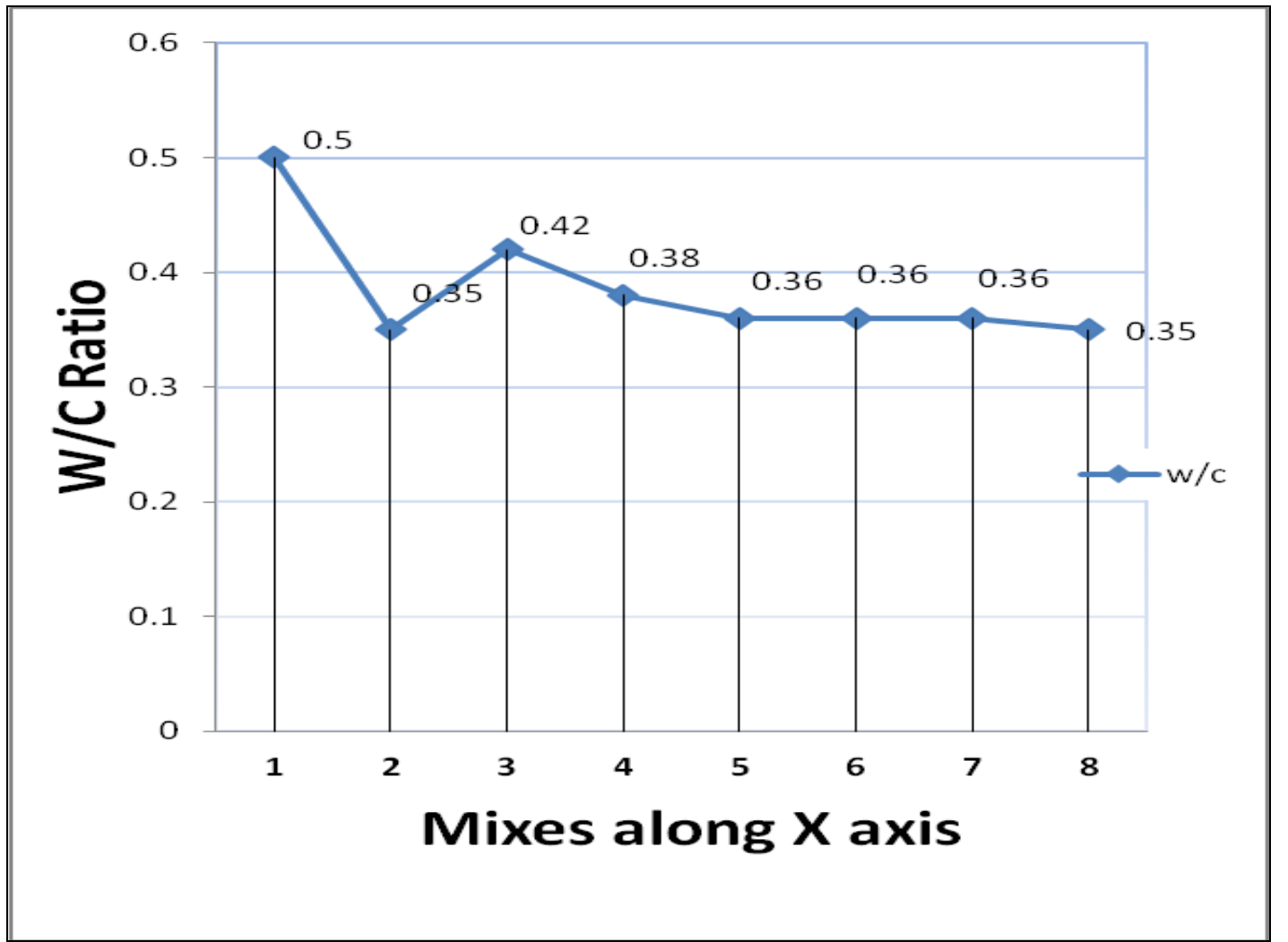

Chart 1: Graph showing w/c ratio for various mixes.

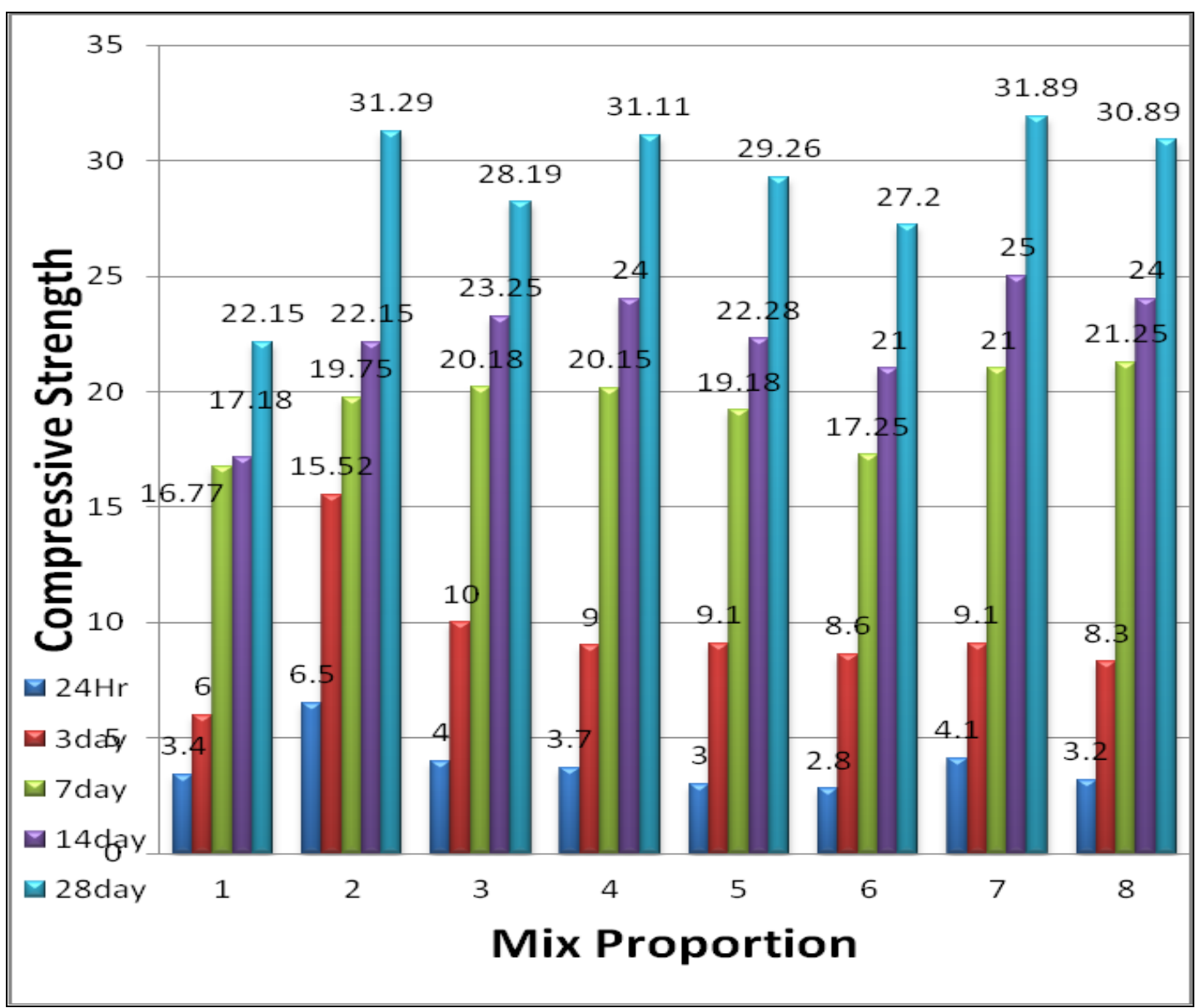

Chart 2: Graph showing results of compressive strength test. 
5) Replacements of cement by fly ash have resulted in considerable variation in the properties of fresh concrete. Incorporation of fly ash in concrete increased the cohesiveness of the mix, prevented segregation and resulted in reduced bleeding. Fly ash concretes have been found to be amiable to compaction than the mixes without FA.

6) Higher percentages of fly ash can cause a change in color of the mix.

7) From 7 to 28 days the rates of strength development have been found to be similar for control (without fly ash) and fly ash concretes. However, up to 7 days control concrete develops strength at a much faster rate than fly ash concrete.

8) The percentage reductions in strength of fly ash concretes w.r.t control concrete $(50 \%$ crushed and natural sand mix without FA is referred here as control concrete) have been observed to be remarkably high up to 7 days and thereafter reduced drastically. At early ages fly ash behaves more or less as an inert material, fly ash replacement will call for reduction in primary cementitious material and hence strength reduces significantly. However, at latter ages pozzolanic activity becomes significant resulting in considerable improvement in strength thereby lowering the rate of strength reduction.

9) When Fly Ash was used, it was observed that there was a reduction in water demand by concrete, probably due to the fact that FA helps to increase the workability of concrete very similar to the action of water reducing admixture. This reduction in water ultimately gave a increase in strength as seen in the graph below.

10) Also there was a reduction in dose of admixture from $1 \%$ to $0.8 \%$, still desired workability was achieved. Even though the w/c ratio for $25 \%$ replacement of cement by fly ash is lesser as compare to $15 \%$ replacement, still the compressive strength is lower. Hence $25 \%$ replacement will be not suggestible in our case.

11) In case of GGBS, it was found that concrete behaved little similar as in case of fly ash by showing comparative lower initial strength and satisfactory 28th day strength, again the workability was achieved at lower w/c and at lower admixture dose .The graphs of compressive strength result and variation in w/c ratio are shown below.

12) The setting time of concrete is influenced by many factors, in particular temperature and water/cement ratio. With GGBS, the setting time will be extended slightly, perhaps by about 30 minutes. The effect will be more pronounced at high levels of GGBS and/or low temperatures. An extended setting time is advantageous in that the concrete will remain workable longer and there will be less risk of cold joints. This is particularly useful in warm weather.

13) The w/c ratio reduced from 0.42 to 0.36 when GGBS was used, as compare to the control mix.(50\% CS and NS without GGBS). Thus the differences in rheological behaviour between GGBS and Portland cement may enable a small reduction in water content to achieve equivalent consistence class. Thus reduction in $\mathrm{w} / \mathrm{c}$ ratio will help in improving the compressive strength.

14) While concretes containing GGBS have a similar, or slightly improved consistence to equivalent Portland cement concretes, fresh concrete containing GGBS tends to require less energy for movement. This makes it easier to place and compact, especially when pumping or using mechanical vibration. In addition, it will retain its workability for longer.

15) The graph shows that there was a reduction in strength by about $1 \mathrm{MPa}$ when GGBS was increased from $40 \%$ to $50 \%$.With the same content of cementitious material (the total weight of Portland cement plus GGBS), similar 28-day strengths to Portland cement will normally be achieved when using up to 40 per cent GGBS. At higher GGBS percentages the cementitious content may need to be increased to achieve equivalent 28-day strength.

16) GGBS concrete gains strength more steadily than equivalent concrete made with Portland cement. For the same 28-day strength, a GGBS concrete will have lower strength at early ages but its long-term strength will be greater. The reduction in earlystrength will be most noticeable at high GGBS levels and low temperatures.

17) Ground granulated blast furnace slag is off-white in colour and substantially lighter than Portland cement. This whiter colour is also seen in concrete made with GGBS, especially at addition rates of 50 per cent and above. The more aesthetically pleasing appearance of GGBS concrete can help soften the visual impact of large structures such as bridges and retaining walls. For coloured concrete, the pigment requirements are often reduced with GGBS and the colours are brighter.

\section{REFERENCES}

[1]. Nimitha Vijayaraghavan and A.S. Wayal "Effect of manufactured sand on compressive strength and workability of concrete"International Journal of Structural and Civil Engineering Research ,Vol02,No04,Nov 2013.,pp229-232 [2]. Shanmugapriya T and Uma R N (2012),"Optimization of Partial Replacement of M-Sand By Natural Sand In High Performance Concrete With Silica Fume", International Journal of Engineering Sciences \& Emerging Technologies, Vol. 2, pp. 73-80.

[3]. Saeed Ahmad and Shahid Mahmood (2008), "Effects of Crushed And Natural Sand on The Properties of Fresh and Hardened Concrete", 33rd Conference on Our World In Concrete \& Structures, Singapore, pp. 25-27.

[4]. Syam Prakash V (2007), "Ready Mixed Concrete Using Manufactured Sand As Fine Aggregate", 32nd Conference on Our World In Concrete \& Structures: Singapore.

[5]. Mahendra R Chitlange and Prakash S Pajgade (2010), "Strength Appraisal of Artificial Sand as Fine Aggregate", In SFRC Asian Research Publishing Network Journal of Engineering and Applied Sciences, Vol. 5, pp. 34-38. 
[6]. B Balapgol ,S A Kulkarni, K M Bajoria, “ Strength and durability of concrete with crushed sand", 27th Conference on OUR WORLD IN CONCRETE \& STRUCTURES: 29 30 August 2002, Singapore, pp179-184.

[7]. A.H.L.Swaroop1, K.Venkateswararao2, Prof .P Kodandaramarao "Durability Studies On Concrete With Fly Ash \& GGBS" , International Journal of Engineering Research and Applications (IJERA) Vol. 3, Issue 4, Jul-Aug 2013, pp.285-289.

[8]. Cement and Concrete Association of Australia \& Standards Australia 2002, Guide toConcrete Construction, Cement and Concrete Association of Australis, Sydney.

[9]. Hudson, B., 1998, 'Impact of Manufactured Sand in Concrete', Quarry, vol. 6, December 1998, pp. 31-34.

[10]. Corrigan, B., D’Sourza, B. Dumitru, 'New Generation Admixture for Improvement of Concrete with Manufactured Sands', Publication Unknown.

[11]. Anand Kumar B .G. ,Effective Utilization of Fly Ash and Supplementary Cementitious Materialsin Construction Industry Department of Civil Engineering, R V College of Engineering, Bangalore. International Journal of Advanced Technology in Civil Engineering, ISSN: $2231-5721$, Volume-1, Issue-2, 2012, pp107-114.

\section{BIOGRAPHIES}

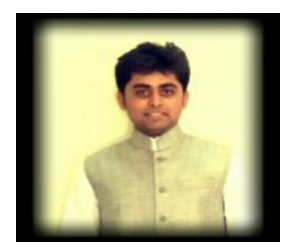

Er. Karan Verma, presently pursuing Masters Degree in Structural Engineering .Has worked as civil contractor in Amravati city after completion of B.E from MIT ,Pune.

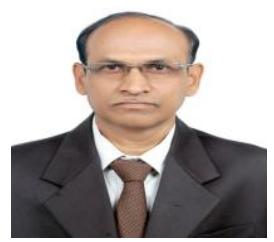

Dr. P.S.Pajgade is presently working as Professor at Prof.Ram Meghe Institute of Technology and Research ,Badnera, Amravati 